Papers and Proceedings of the Royal Society of Tasmania, Volume 113, 1979.

(ms. received $2 \cdot 10.1978$ )

"FEMALE SETTLER MARTHA HAYES" 1786-1871

by Frank Bolt

Kingston Beach

(with one table)

ABSTRACT

BOLT, F., 1979 (20 vii): "Female settler Martha Hayes" 1786-1871. Pco. Proc. R. Soc. Tasm., 113: 155-167. ISSN 0080-4703. 39 Kingston Heights, Kingston Beach, Tasmania, Australia.

Martha Hayes (1786-1871) came to Australia in 1803 as the daughter of a female convict. She formed a liaison with Lt. John Bowen and had two daughters by him. Later she married Hobart settler Andrew Whitehead and, after his death, police clerk Barnard Williamson.

Martha lived in Hobart Town from 1804 onward, and her life is closely interwoven with many colourful characters who lived in Hobart during the first few decades.

\title{
INTRODUCTION
}

During a recent professional project I kept coming across the name of Martha Hayes, a girl to whom various things were attributed depending on what popular press article one read. Responsible information however was hard to come by, and in the end I decided to satisfy my curiosity - hence this paper.

Martha turned out to be a girl from London whose mother was transported to Sydney as a convict in 1803 on the "Glatton". In all probability, Martha came out with her mother (as did several other children of transported female convicts), and while on board became acquainted with a young naval lieutenant John Bowen, who soon after arrival in Sydney received a commission from Governor King to establish a settlement at Risdon Cove in Van Diemens Land. After Bowen's return to England Martha eventually married ex-convict Andrew Whitehead, and her subsequent iffe and environment appeared to be worth recording as they throw an interesting light on the life of some of the early settlers of Hobart Town.

The elucidation of her early 1 ife was not without its complications; proof of her existence before May 1803 is not available, and I have had to assume that she came out with her convict-mother on the "Glatton", and on it met John Bowen. The 1ikelihood of this assumption being correct is many times that of any other version, and I can only leave it at that until other evidence turns up.

Similarly, there is the intriguing question of who travelled from Port rhillip to Port Jackson to inquire about Martha's mother, by then serving her time in Sydney. What was recorded as intended to happen and what actually did happen may be two different things, and on balance I favour the version that it was Thomas Hayes who went to Sydney, especially as he is mentioned by name in a dispatch from Governor King to collins.

The details of Martha's later life are followed much more readily as a result of the facts and clues contained in Knopwood's recently published diary, and full credit must be given here to this magnificent effort by Mary Nicholls. Without her 
painstaking transcription of the old gossip's notes and comments a paper such as this would not have been possible.

The story is not complete; interesting gaps remajn, and I hope that it may induce those who are in the possession of related documents or family papers or other articles to come forward, thus adding further detail to this picture of some of Hobart's early settlers.

One final point that struck me very much during the compilation of Martha's story is this: although the society of her days was very stratified, it is amazing to see how all these people intermingle, know each other, and together make the best of a potentially (and often actually) disastrous situation. I am convinced that in those days the foundations were laid of a new social structure to fit a new country, a structure that is still clearly recognisable today.

I like to express my thanks to several descendants of the Hayes families, to Geoffrey Stilwell of the State Library of Tasmania, the staff of the Archives Office of Tasmania, Mrs. M.J. Tipping of Melbourne, and to the staff of the various libraries in Sydney and Melbourne as well as a number of others who were not afraid of discussing skeletons in the cupboard. Fortunately, these matters are no longer quite as emotional as they used to be.

\section{THE 'PRIVATE CONCERNS'}

Early in 1801 a Henry and Mary Maria Hayes were arrested in London on suspicion of having received stolen goods: a trunk and other valuables worth about $\mathfrak{L}^{\circ} 1000 .{ }^{1}$

They were committed to the Newgate Prison by a Mr. Bond on May 15, 1801, and were then described as follows: Henry Hayes, a calico-glazier, from Tetbury (a small village in the Cotswolds), Gloucestershire, age 39, height $5^{\prime} 7^{\prime \prime}$, brown hair and with a dark complexion. His wife Mary came from London, was 35 years old, height $5^{\prime} 4^{\prime \prime}$, had grey eyes, brown hair and also had a dark complexion. ${ }^{2}$ The charge was that they had received goods which had been stolen by a Thomas Collett, alias 'Putty'. The case was tried by Judge Grose who found Henry not guilty. Mary however was sentenced to fourteen years transportation ${ }^{3}$, and left for Port Jackson on the "Glatton" in January 1803, the ship on which a John Bowen served as a naval lieutenant.

Henry and Mary had a daughter Martha (see genealogical table) and it must be assumed that this daughter accompanied her mother on the "Glatton" in the same way as several other female convicts on board this ship had some or all of their children with them. At the time Martha was sixteen years old and at that age she would have been classified as a free passenger. So far, no confirmed passenger list of the "Glatton" has been found."

Once on board the "Glatton" it would not have been long before Martha and John Bowen met; an attachment between the two developed, and soon after the arrival in Sydney Martha commenced to live with Bowen. ${ }^{5}$ Her mother in the meantime had been handed over to the authorities in sydney, and nothing is known of her circunstances in Sydney after she left the "Glatton". ${ }^{6}$

Bowen arrived at a time when Governor King was in need of a suitable officer to take charge of a proposed settlement on the Derwent in Van Diemen's Land. Bowen was ambitious, offered his services and was accepted. To assist him, he persuaded several of his acquaintances from the "Glatton" to join him, and after a number of false starts they eventually arrived in Risdon Cove. ${ }^{7}$ The actual unloading of the ships began the day after their arrival, i.e. Monday September 12th, 1803, and Martha, who had joined Bowen on this expedition, prided herself for the rest of her life on the fact that she 
Frank Bolt

had been the first white woman to set foot in Van Diemen's Land, having been carried ashore by Bowen's men. 8 The settlement at Risdon Cove was named Hobart (after the Secretary of the Colonies of those days, Lord Hobart), and consisted of a collection of about three dozen simple huts or tents. To the girl fresh from London the new colonial life must have seemed very primitive indeed.

In the meantime, Henry Hayes had decided to follow his wife and daughter, and when Lord Hobart advertised for volunteer settlers for a new settlement in Port Phillip, ${ }^{9}$ Henry was among those whose application was accepted. A list by UnderSecretary John Sullivan to Governor King described Henry as a carpenter aged 35 , and noted that he had received 'very favourable testimonies' about Henry Hayes from a $\mathrm{J}$. Savage of Sherrard Street and a J. Lambert of Titchborn Street, London. ${ }^{10}$ On the same list of accepted settlers is also mentioned a Thonas Hayes, a millwright, with a wife and two children. Although Henry and Thomas will have known each other very well from 1803 onward, no reference has been found which definitely establishes a family relationship between them. ${ }^{11}$ The name Hayes occurs very frequently indeed on the lists of early arrivals in Australia, both as free settlers and as convicts.

The settlers left Yarmouth on the "Ocean" in April 1803 in company of the convict transport "Calcutta". This convoy was being sent by the British Government to establish a new settlement in Port Phillip, thus claiming that part of New Holland. The expedition was under the command of Lt. Governor David Collins, who had a number of senior civil and military officers with him to assist him in his task, one of them being a chaplain, the Rev. Robert Knopwood.

Very little is known about Henry, so that one gets the impression that he was a somewhat shy and perhaps a withdrawn person who never drew any attention, and it is also known that he was the only settler who could not write his name. 12 Matthew Bowden in his 'Journal of the outward Journey' described him as a carpenter with a wife who was a convict in Port Jackson.

Early in October 1803 the convoy arrived in Port Phillip where, due to the very difficult conditions on shore, most of the settlers had to remain on board for the time being. The captain of the "Ocean", however, wanted to take his ship to China for trading purposes, and for this reason his passengers and cargo were a few days 1 ater transferred to the "Calcutta", these passengers including Thomas Hayes and his family. The "Ocean" then left, but when it dropped in at Port Jackson Gov. King chartered the ship again for government purposes and sent it back to assist Collins, who by that time was known to have second thoughts about Port Philip as a suitable place to settle. Collins had indeed decided to cut his losses and was considering a new location either at Fort Dalrymple at the mouth of the Tamar or at the Derwent in southern Tasmania. For this reason he sent the "Lady Nelson" to survey the entrance to the Tamar and its environment, and while awaiting her return Collins offered his settlers a choice: stay with me come-what-may or sail in the "Calcutta" to Port Jackson. Nearly all indicated that they wished to stay with him, but the settlers leaving with the "Calcutta" included Thomas Hayes and his family. ${ }^{3}$

We cannot be sure about the motivation of this decision by Thomas Hayes. On the face of it he chose the comparative security of Sydney rather than the unknowns of a second attempt in Tasmania. In view of his early return to Collins, however, a more likely explanation is that he used the opportunity to visit sydney for the purpose of making inquiries about convict woman Mary Hayes on behalf of Henry Hayes, who either lacked the opportunity or the courage to do so himself.

As it was, events turned out to be extremely fortunate for Henry and his Mary. Shortly after the arrival of the "Calcutta" in Sydney, John Bowen the Commandant of the smal1 settlement at Risdon Cove on the Derwent turned up in port with a few mutinous 
soldiers in order to bring them to tria1. ${ }^{14}$ Governor King was furious with Bowen for absenting himself from his post at the Derwent just when at any minute a major French expedition might sail up the river, and promptly sent him back in the "Integrity" with instructions to hand over his command to Collins should the latter indeed turn up.

This departure of a ship which was to meet Collins' party gave Thomas Hayes a golden opportunity to request Gov. King permission to join Collins after a.l1, and to take Mary Hayes with him. King gave his permission ${ }^{15}$, and when Bowen and his party eventually turned up in the Derwent (nissing the foundation of Hobart by a few days), he had not only settler Thomas Hayes and his family with him, but also Martha's mother Mary Hayes. 16

And 5o, after three years of separation and adventure, the Hayes family was together again.

A few days prior to Bowen's return, the settlers who had come with Collins had been taken 'further up the river'17 to the muddy shores of what is now New Town Bay, near the present site of the Queens Walk Recreation ground just below "Runnymede". There they were dumped ashore, and although Collins and Knopwood visited that same day the Risdon Cove settlement just across the river, the event did not even draw a mention in Knopwood's diary. (Probable reason: Collins had misgivings about the settler's choice of New Town Bay 18 and wanted to demonstrate that he washed his hands of their choice). The settlers however were in no mood to go through the Port Phillip experience of dry sand and lack of water again, did what they thought was right, and went for the rich and moist soil inland from New Town Bay. 19 They suffered much hardship as they huddled in makeshift tents and even hollow trees on the banks of the New Town Rivulet while surveyors hacked their way through dense virgin forests to survey the 100-acres allotments which had been promised to the settlers before they left England nearly a year before. 20 Eventually, the 1 and allotted to Henry Hayes stretched between the present New Town High School and Pedder Street. Thomas Hayes became his neighbour on the east, their common boundary being what is now Montagu Street. The next strip of land was occupied by Thomas Isse1l, while the stretch of 1 and between his eastern boundary and the beach at Cornelian Bay became the Government farm, ${ }^{20}$ of which ex-convict Andrew whitehead would becone the manager within a few years.

Henry called his property 'Henrietta Farm', and his house probably stood on the very spot where today the New Town High School stands; the house soon became known as a place where visitors were always welcome, Knopwood often being among them and Martha spent much time on the farm after Bowen left her in 1804. There also was very much contact between the settlers as a group; and it was not long before she took her place among them as their equal.

While Bowen remained in charge of the settlenent at Risdon Cove, Martha continued to live with him and will have witnessed his trials and tribulations as Commandant of the first settlement in Tasmania: the laziness, insubordination and mutiny of his soldiers and officers, and later the affray with the natives.

In March 1804 Knopwood stayed for a few days with Bowen (probably at the request of Collins, to keep an eye on what was going on) and noted one day in his diary: ". . this morning Gov. Bowen's young friend was confined to her bed". So was noted the birth of Henrietta Bowen, the first European person to be born in Tasmania.21 About this time Bowen's relationships with Gov. King and Collins became embarrassing as he kept on postponing his proposed return to England. Bowen obviously did not wish to leave Tasmania before having 'settled his private concerns' as King noted several times: ${ }^{2}$ providing as well as he could for Martha and their daughter Henrietta. In the end, however, he could not delay his departure any Ionger, and arranged to return to Sydney in the "ocean" which was to leave Hobart in about July. 
Frank Bolt

GENEALOGICAL TABLE

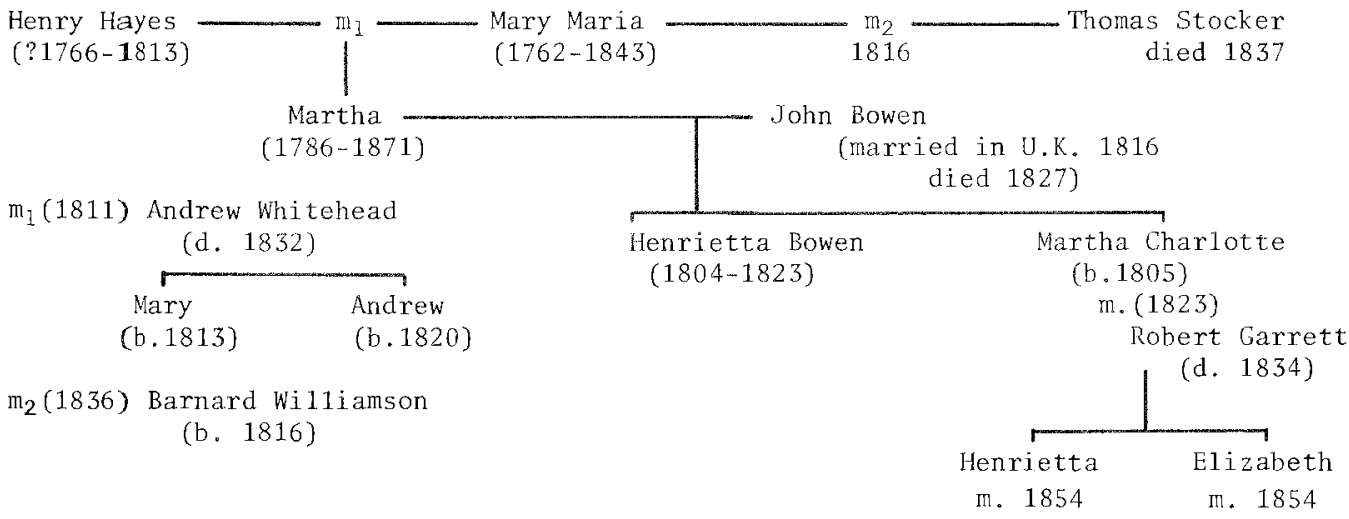

Of major advantage to Martha was Bowen's action in arranging for Collins to declare her a settler.23 This gave her the right to receive government rations over the next few years, a grant of land (although she only got half the usual 100 acres), convict servants to clear and work the land and some seed and live stock to get the farm going. Later surveys however showed the area of her grant to be more like 65 acres, while Martha also turned out to be a clever manager: her farm prospered and in later years became a worthwhile asset, as the retums of statistical surveys of those days show. The location of the grant covered the area of what is now the eastern end of Lampton Avenue, and it is likely that this street started its existence as a track over her farm with paddocks and wheatfields on either side.

Shortly before his departure in August 1804, Bowen also built Martha a 'house', probably a simple timber hut, and this was the place where he spent his last few days in Van Diemen's Land with his Martha. ${ }^{24}$ It was to this 'house' during these last few days that he invited some of his closer friends for a last meal: Knopwood, wilson etc. But then the final embarkation orders are given: Bowen and Martha part, and on his last night in Hobart on board of the 'Ocean' he said goodbye to Knopwood, who especially came aboard to farewell his friend. Early the next morning the 'Ocean' left Sullivans Cove, and Bowen never saw Van Diemen's Land or Martha again.

As noted earlier, Bowen before his departure had gone to some considerable length to provide for Martha and Henrietta. Apart from the arrangements with Collins to have Martha declared a 'female settler' which gave her considerable advantages, Bowen also got Knopwood to take a special interest in the well-being of Martha and her daughter (a task which he performed well for many years after), whilst on his return to Sydney Bowen made arrangements to have pigs, wheat and maize sent to her.25

Collins became godfather to one of the children, and Bowen himself seems to have sent gifts from England on appropriate occasions.25 At the time of Bowen's death the 'Tasmanian' of 14.3.1828 noted that 'his daughter, Mrs. Dr. Garrett from Pittwater (Sorell) had been well provided for'. In later years Bowen tried several times to return to Tasmania, but only on his own terms. When the news of the death of Collins became known in London Bowen offered his services to Robert Peel but was rejected, 27 ostensibly on a technicality. His services were rejected again in 1819 when he offered to join Commissioner Bigge as an expert on the situation in Van Diemen's Land in which, he reminded Under-Secretary Goulburn, he had established the first settlement. 28 
Bowen married in 1816, but died without any further children in 1827 'after a long and painful illness'.

\section{THE 'TEDIOUS COURTSHIPS'}

Soon after the departure of Bowen, Martha realised that she was expecting Bowen's second child, and after some initial hesitation she and her mother decided to visit Knopwood in his tent on the shore of Sullivans Cove.29

Knopwood promised his help, and to underscore his promise he visited the Hayes family several times during the coming sumer, and recorded in Apri1 1805 the birth of Martha Charlotte. After the birth knopwood continued to visit the Hayes farily, but at the end of that month he entered a curious event in his diary: "At half past eleven I met the Lt. Gov. and Mrs. Powers (Collins' mistress). She told me that they were coming to my house to speak to me. The Governor said that he could not make it convenient to go to the farm and have Martha Hayes' children xtiand. I asked him if he did not mean to stand for the child. His answer was 'no', but requested that I would go there. I walked and of course found them unprepared with godfather and godmother as the Lt. Gov. and Mrs. Powers had promised to stand for the child".

The next day, Martha and her mother went to see Knopwood to discuss the situation. ${ }^{30}$ Obviously, Mrs. Powers had persuaded Collins not to fulfil the promise which he apparently had made at some time in the past, and Knopwood probably advised Martha to let the matter rest for a while. His advice was right, because after some months Collins changed his mind; Knopwood then baptised both children while the Governor 'stood for one' (probably Martha Charlotte). 31

Later that year Martha's father Henry was visited by Joseph Holt, a visitor to Hobart who had been asked by Collins to give him his opinion on the skill and efficiency with which the new farmer-settlers along the shores of the Derwent went about their job (reply: not very we11). Henry and his wife Mary were then living in their small farm cottage along the New Town Creek, while Martha also happened to be there at that occasion. Henry and his wife were found to be making a living from 'pleating straw for the ladies', and were augmenting their income by raising dogs, selling the young pups for ten pounds each (a very considerable sum in those days). It was at this occasion that Holt made his wellknown tribute to Martha: $1 .$. the daughter was a beautiful girl; she was the prettiest violet I saw growing on the Derwent'. He also summed up Martha's mother very quickly: '... the old lady (she was in fact then only 44!) was very pleasant, as my friend and I carried a bottle of good rum with us... 32 .

During the years after Bowen's departure, Martha's farm on the shores of the Prince-of-Wales Bay began to improve steadily. When Bowen left she started her farm with eight sheep and two goats. Two years later she had two acres under cultivation, and ran two cows, 35 sheep and 14 goats. 33 A year 1 ater still in 1807 she had managed to increase her acreage to five. She then had still only two cows and on 1 y 11 goats, but her flock of sheep had grown to 40; at that time she was also responsible for two convicts, very likely working for her as labourers on the farm. In 1809 there were seven acres cleared and under cultivation on which she ran three cattle, 70 sheep and seven goats. 34 It is clear from this that she not only managed quite well as 'a female settler' but that she also was in a privileged position during the terrible hunger winters which occurred during the first few years of the settlement, when food was very scarce indeed. The surrounding settlers liked her and considered her as an equal. When for instance a proper bridge across the New Town Creek became desirable (possibly the one which used to be at the lower end of Bay Road), she joined others at a public meeting of the settlers and put her signature under an agreement to fund the cost of the bridge with those of the others. ${ }^{35}$ Later she and her mother appear to be 
the 'executrixes" of the will of Thomas Preston, a neighbouring settler who died after a fall from his horse. 36

From al1 accounts therefore she not on $1 y$ was an attractive woman but also one who had shown herself to be a clever manager of her affairs, and it was thus no wonder that she soon began to attract the attention of one of her neighbours, Andrew Whitehead, a convict who had come out with Collins in 1803, and who was eighteen years her senior. He had turned out to be a good famer, and after receiving an absolute remission of his sentence ${ }^{37}$ Collins appointed him in charge of the somewhat neglected Government farm at Comelian Bay, which covered the present-day sportsfield and cemetery in that area. 37

In 1811 the two were married by Knopwood, and from then on Whitehead managed the two farms together with the cattle owned by Martha's two daughters, who had adopted the name "Bowen" as their sumame. 38 Encouraged and aided by their grandfather Henry Hayes (who had even named his own farm 'Henrietta Farm' after the eldest gir1) they seem to have owned a fair amount of stock, and even as teenage girls are frequently listed as the suppliers of fresh meat to the government store in Hobart. Soon their interests diversified further, and together with their grand(step) father T.W. Stocker they obtained interests in the Ross area and provided some or all of the funds for the building of the first 'Man-of'Ross' Hotel in the centre of that town. 38

In 1813 Macquarie granted the land covered by the government farm at Cornelian Bay to Whitehead, and at that time 1 ife must have looked decidedly good to Andrew and Martha. Earlier that year a daughter Mary had been born to them; Martha still had the farm at the Prince-of-Wales Bay, and in general enjoyed her social position within the New Town society. Knopwood was a frequent guest as were several of the military officers from Hobart Town, and even Gov. Macquarie from Sydney visited their farmstead and was moved to describe whitehead as 'a respectable farmer'. ${ }^{39}$ It must be stressed however that Whitehead and his household were an exception. Oxley confirmed the earlier opinion of Holt in $1805^{32}$ when he reported in $1810^{41}$ : '... few of them originally were farmers or understand anything about agriculture; they have in consequence so exhausted their ground by repeated crops of the same grain that it now produces 1ittle or nothing'. Excluding Pitt, all the original settlers along the New Town Creek sold or lost their grant within the next decade or so, and the fine homes that can still be found along this creek were built by the second or third generation of owners, people who knew what land ownership was all about.

An interesting sidelight on their life is that it was probably on whitehead's land that surveyor James Meehan in the winter of 1813 recorded the presence of a race track - the earliest known reference to the racing sport in Tasmania. The exact location of their farmstead is not known at present; a likely spot however may be indicated by the old foundations in the garden of the house of the caretaker of the Cornelian Bay cemetery. ${ }^{40}$

Unfortunately the good times in the Whitehead household were not to last. In 1814,2800 gallons of liquor (about two gallons per head of population; a colossal quantity for that time) was smuggled ashore from the 'Argo', Whitehead and a celebrated ex-convict Dennis McCarty being heavily involved in the actual operation. The barrels were very likely landed on the beach of Cornelian Bay, and then stored in the nearby farm (Whitehead's) for further distribution in thirsty Hobart Town. 42 But someone talked, and Gov. Davey, although he himself was very likely one of the waiting customers, was forced to send an officer from Government louse to confiscate the lot.

The seizure caused great consternation within the Hobart community, and it is amusing to follow in Knopwood's diary the hurried consultations that took place. Soon the plan is ready: everyone professes not to know the regulations relating to the 
disposal of 'the spirits' (permission should have been obtained first from Macquarie who complained later that even in sydney officers from the highest rank did not have so much liquor on their hands for private consumption as some of the Hobart convicts, and he mentioned two by name), 43 and a formal auction was arranged. For some officially unexplained reason Edward Lord (a former Commandant of Hobart) was able to buy most or all of the stock, 44 and the sigh of relief throughout Hobart Town was very audible indeed. The evening after the auction a party was held at Knopwood's house at Battery loint, the guests including Whitehead, McCarty and Captain Carr, and the main topic of conversation does not need to be guessed at. 45

The sequel to the story became a comedy. Davey had to punish somebody, so he sentenced Whitehead to house arrest, McCarty, to a prison sentence, a sentence which was to be spent in Sydney - apparently Davey could not under the circumstances visualise an effective imprisonment of McCarty in Hobart Town. It took a great1y bewildered Macquarie on $1 y$ one drink with McCarty to find out what really happened before realising that he was beaten. Nevertheless he was furious, and let Davey know so in no uncertain terms: '.. I think that Whitehead was even more guilty than McCarty; the spirits were (after all) seized in Whitehead's house'. McCarty however got fed up with being the lone scapegoat in the whole affair, and when he began to threaten to sue Davey for wrongful arrest, trespassing and stealing, Macquarie thought the better of it and remitted the remainder of McCarty's sentence. Using his newly purchased schooner 'Geordy', McCarty prompt1y retumed to Hobart, where his unexpected re-appearance on the wharf was a good-enough excuse for a welcome-home party at the Whiteheads. The next day Davey released Whitehead from his house arrest. 45

In this environment the two Bowen girls continued to grow up and gradually began to take part in the social life of Hobart Town. They visited Knopwood from time to time, and busied themselves looking after him during his frequent bouts of illness. Always together, they also made it an annual ritual to visit him when the fruit in his garden was ripe, while their grandmother made sure that the raspberries from his garden were made into a delicious jam. ${ }^{46}$

During these eventful but still happy years knopwood remained a regular guest at the farm. He usual1y walked to New Town after the church service in a barn or in the open air at Hobart Town (which at that time was still without a proper church building), and then would have dinner with the whiteheads. He also regularly dropped in once or twice during the week, and especially Andrew, one of the family, returned these visits almost every week by calling on Knopwood. They would then 'have a pipe', a drink and a meal, and often enjoyed the company of other friends of Knopwood, usually military officers or visitors from ships in port. This lifestyle continued till late in 1817 when Whitehead sold his farm at Cornelian Bay and moved to Herdsmans Cove near Bridgewater. 47

Martha also disposed of her farm about that time, and in spring 1817 Knopwood dined for the last time with the Whiteheads in the homestead near the beach where he so often had spent so many happy hours. Only one year ago he himself had had to dispose of his own cottage on the waterfront of Sullivans Cove, and quite clearly the small world of Hobart Town was not going to be the same for them any more. ${ }^{48}$

The change from Cornelian Bay to the house near the shore of Herdsmans Cove caused many problems for the Whiteheads. For Andrew there were financial problems and farming problems: during one cold night in October he lost 50 sheep, an experience which apparently was new to the settlers. ${ }^{49}$ For Martha it meant not having the two Bowen girls around the house any more. Their education made it necessary for them to be in town, and arrangements were made for them to live with their grandmother Mary ${ }^{5}$, who soon after the death of her husband Henry in 1813 had begun a new life as the owner of the Derwent Hotel in Elizabeth Street, behind the present G.P.0.50. 
Frank Bolt

One gets the impression that grandma Hayes thought it about time that the girls received 'a broader out10ok', and she seems to have done the job with gusto. She gave the girls some kind of a 'coming-out' party 51 and also made sure that they were seen in the right places at the right time. 52 In between all this, grandma Hayes did not forget her own interest. One of the notable customers in her hotel was Thomas $W$. Stocker, a well-known settler with a good eye for business (farming, coach transport between Hobart and Launceston, hote1s, real estate etc.). Soon the two came to an understanding, and in 1816 knopwood became the celebrant of their marriage. Noticed the "Hobart Town Gazette" of the day (somewhat tongue-in-cheek): '... was married, by the Rev. R. Knopwood, at the Derwent Hote1, Thomas Stocker to Maria Hayes, Widow, of the Derwent Hotel, Elizabeth Street; after a long and tedious courtship of two years'.53

The finer points of the joke are no longer known, but the word 'tedious' and the underlining of the word "two" stimulate the imagination. However, a great time was had by all and sundry during the wedding festivities, including the pickpocket who relieved Stocker of his silver-and-gold watch during the merrymaking: 53

Beginning with the move to Herdsmans Cove we seem to notice a gradual change in the position if not the fortune of Whitehead. He still kept on delivering large quantities of meat to the government stores in Hobart, but in May 1818 he apparently was forced to advertise a request 'that all persons who stand indebted to him will pay the amounts of their respective Debts', as he in turn is also being called upon by his creditors to 'liquidate several claims'.54 Presumably his financial embarrassment passed, as he kept on selling large quantities of meat to the government stores.

Andrew and Martha had a second child Andrew in 1820. Little is known about their circumstances during that period, but they still seem to be doing reasonably well. Andrew for a while held a licence for his house at the Cove ${ }^{55}$, and in 1819 even the Governor in the company of Knopwood stayed at the farm56. It is however the very last time that knopwood does so, and one begins to wonder what has happened.

An interesting note on the social standing of the Whiteheads at that time can be found in a letter from Gov. Sorell to Commissioner Bigge in which he explains the basis of the allocation of seats in the newly built St. Davids Church: '... relative to rank and person'. Military officers occupied the front row, followed by Civil officers, important merchants, settlers and servants, with the convicts having to make the best of the situation in the rear of the building. In this pecking order, the whitehead and the Stocker households shared the sixth out of eleven rows. 57

Notwithstanding the change in relationship between Knopwood and Andrew Whitehead, the Bowen girls still kept visiting the ageing chaplain, while Martha also accompanied them occasionally, especially in summertime and on the all-too-frequent occasions when Knopwood was i11. Knopwood still enjoyed the company of Martha very much, and at one stage even went to visit her when she stayed with her mother at the Derwent Hote1. 58 No doubt the bonds of the past were still present, and this became very clear when Henrietta Bowen (the eldest) became seriously ill and died (June 1823). Knopwood stayed with her during her last hours, and after her death described her as 'one of the finest girls on earth'. He later tells us that her funeral '... was attended by the first people of distinction'. 59 Henrietta was buried in St. David's Cemetery, and from an inscription on her tomb it appears that it was erected by her grandmother, Mary Maria Stocker, 60

Early in 1822 arrived in Hobart Town, via India, a Dr. Robert Garrett, 24, a settler from Wigtownshire in Scotland, who sought to establish himself in the colonies as 'a surgeon'.61 He seems to have been a pleasant and gregarious young man who not only managed to get himself appointed as a district doctor in sorell, but who also became a member of Knopwood's circle of friends. Knopwood in those days was not very 
wel1, and Garrett became his personal physician. As such, it was not long before he met the Bowen girls, and together they spent many hours nursing either Knopwood himself or his ward Elizabeth Mack back to health again.

Robert and Charlotte fell in love, and in December 1823 they were married in St. Davids Church - the wedding ceremony not being performed by knopwood but by the Rev. Bedford, probably because it was no longer Knopwood's parish. The notice in the "Hobart Town Gazette" is not 1ong, but it does mention the fact that the bride was the daughter of Capt. John Bowen. 62

A1though Martha during this time remained in the background she was still very much there. It was she who made sure that knopwood was being looked after, and that he received the necessary care and attention. Her husband's relations with Knopwood however kept on deteriorating, but Andrew seemed to have made at least one last effort to patch things up again by looking him up when Knopwood made a visit to New Norfolk. Knopwood refers to the meeting briefly ${ }^{63}$, but it is the last time that Andrew Whitehead is mentioned in his diary - a sad end to a once very strong friendship.

Over the next few years it was Martha's daughter Charlotte who kept on being in the news. When for instance in March 1828 the news of the death of Bowen became known in Hobart Town, the 'Tasmanian' of 22.10.1828 mentions that 'his daughter, Mrs. Dr. Garrett of Pitwater (Sorell) has been well provided for by her late father', another sign that Bowen retained an interest throughout his life in the well being of his daughter. The nature of these provisions are not known - at that time Charlotte and her husband had extensive interests in farming properties in Sorell, near Ross and near Westbury. And well they needed these, as Garrett's competence as a doctor was called into question that same year; later he very likely became an alcoholic and eventually was charged again with incompetence but died from a stroke in December 1834 in Launceston. ${ }^{6}$ Robert Garrett should not be confused with his older brother James Garrett who arrived in Hobart Town in December 1828, and who became a we11-known Tasmanian preacher.

In the meantime Andrew Whitehead died in 1832, and Martha possibly stayed on at the farm or at least in the Brighton district, because in 1836 an extraordinary news item appeared in the "Cornwall Chronicle":65

'On the 7th Ultimo (January): Mr. Barnard Williamson, Police Clerk, Brighton, aged 20 , to Mrs. Martha Whitehead, aged 50 , after a long and tedious courtship of two years ${ }^{\prime}$.

We must take this news item as it appeared, but are free to ponder its interpretation. One thing, however, is certain: somebody in the office of the "Cornwall Chronicle" had a very long memory...

Martha's stepfather Stocker died in 183766, followed by her mother Mary in 1843 at the ripe old age of 82 . Of Martha's own later years little is known, while equally little is known about the 20-year old police clerk who was game enough to marry the 50-year old Martha.

In 1854 two of her granddaughters (Henrietta and Elizabeth) married in a double ceremony in St. Geroge's Church in Battery Point 57 , and Martha will also have known most if not all of her great-grandchildren. Her obituary appeared in the "Mercury" of May 15, 1871, followed the next day by a brief salute:

The last of the first - Our obituary notice records the decease of Mrs. Martha Williamson at the residence of her son-in-law, Mr. Thomas Devine, of Brown's River. In the year 1803 sixty eight years ago, when this colony was founded, the deceased, then Miss Hayes, was the first white woman - or rather English 
Frank BoTt

young lady, for she was only seventeen - that set foot on the island, and this she effected after a playfull contest for the honour with a less fortunate rival of her own sex, on the flat where it was at that time intended to establish the capital just below the residence of Mr. T.G. Gregson at Risdon or 'Restdown' as they named the spot in those days. With the exception of one lady who still survives, it is supposed that the deceased was the last of the immigrants who formed the first British settlement in the land we live in'.68

Martha was buried on Wednesday May 17, 1871, after a service in St. David's Church, the same church which she had seen being built, and which was now about to be demolished to make way for a new cathedral. Her last resting place, probably St. Davids' Cemetery in Davey Street, was not officially recorded.

Martha arrived in Tasmania as a statistic only (in his return to King dated 27 th. September 1803 Bowen only describes her as one of the people 'not victualled from the store' $^{69}$, and even the location of her last resting place is unknown, two things she had in common with the thousands of other 'female settlers' who came to this island after her.

They were the ones who stood behind (and with) their menfolk, and who collectively laid the foundation of our environment and our present life-style. May we honour them by knowing about them.

\section{REFERENCES}

1 - Robson, L.L., 1965: CONVICT SETTleRs OF AUSTRAlia. MeZb. Univ. Press, p.83.

2 - It is clear from later references that their ages were mixed up in this document; Henry is 35 and Mary is 39.

3 - PRO 2731.

4 - "Glatton" Indent p. 123 et seq.; Arch. of NSW. Also HRA 1-3, p.534.

5 - CSO 1/374, file 8531. TSA.

6 - She is definitely not the M. Hayes who advertised later in 1803 in the "Sydney Gazette", as these advertisements continued to appear for some time after Martha's mother had left sydney for Hobart, early in 1804.

7 - HRA $1-3$, p. 132 .

8 - "Mercury" 16.5.1871. Strictly speaking she was not the very first European woman to set foot in Tasmania, as it is recorded that the French expedition of D'Entrecasteaux in 1792-93 had a steward on board called Girandin who in fact was a woman in disguise, 'a poor young girl who, betrayed by a disloyal seducer, had fled the righteous anger of her father' as Jurien de la Graviere put it in his 'SOUVENIRS D'UN ADMIRAL' (Paris-1860). Her secret came out when she died shortly after the sick and harrassed crew sailed from Java for France in 1795 (Dunmore, J., 1965: FRENCH EXPLORERS IN THE PACIFIC, I, page 330; Oxford).

It is unlikely that Martha or anyone else in Tasmania at that time knew anything about this.

9 - Recollections of John Hayes - TSA.

10 - HRA 3-1, p.66.

11 - There is no firm indication of the place of origin of Thomas Hayes, while the family tradition is divided in their opinion about his relationship with Henry Hayes.

12 - MS 8, Dixon Library, Sydney.

13 - The matter of the transfer remains puzzling. It clearly states in HRA 3-1, p.56 (King to Collins): "Thomas Hayes, who came out (as) a settler in the "Ocean" and came here (Sydney) in the "Calcutta", as well as Fletcher the stone mason, with 
their families, wish to return to you as settlers. I have therefor given them permission to go in the Integrety for that purpose'. Note 69 on page 797 of that volume does include Henry Hayes among those who transfer from the "Ocean" to the "Calcutta", but note 16 on page 786-787 contradicts note 69 . The first mention of Thomas Hayes on page 787 is in all probability an editing error, and should read Henry Hayes. When Henry Hayes is mentioned in the same note he is among those who have gone with Collins to the Derwent. In view of the evidence on hand and the implications of the possible alternatives I have accepted the latter statement as being correct.

14 - HRA 3-1, p. 55.

15 - HRA 3-1, p. 56.

16 - CO 201/33, p. 242 (microfilm 17, TSA).

17 - HRA 3-1, p. 150

18 - Knopwood 18.2.1804:- M. Nicholls, 1978: KNOPWOODS DIARY, THRA, Hobart.

19 - Hopton, A.J., 1960: J.P. Fawkner, Vict. Hist. Mag., 30: page 38.

20 - see note 9 .

21 - Knopwood 29.3.1804.

22 - HRA 3-1, Page 212.

23 - HRA 3-1, page 109.

24 - Knopwood 30.7.1804.

25 - Wentworth papers A 751, pages 161-62, Mitchell Library.

26 - Bethell, L.S., 1958: VALIEY OF THE DERWENT, Dept. Educ., Tasmania, page 21. Several other decendents have told me similar stories, while some have actual articles to show, one of which in particular is very moving indeed, throwing a very sympathetic light on Bowen. Proof of authenticity of such articles always remains very difficult.

27 - HR-NSN 1811, page 496.

28 - CO 201/95, pages 66-67 (microfilm 46, TSA).

29 - Knopwood 25.10.1804.

30 - Knopwood 30.4.1805.

31 - Knopwood 20.8.1805.

32 - Holt, vol.2, page 249; 1848 .

33 - HRA 3-1, page 255 .

34 - HRA 3-1, pages 422-23.

35 - MS 8, Dixon Iibrary, Sydney.

36 - HTG 18.7.1818.

37 - HRA 3-1, pages 555 and 558 .

38 - CSO 1/374 file 8531, TSA.

39 - Macquarie: JOURNAI etc. 1810-1822, Publ. Library of NSW, page 57.

40 - The present cottage may date from about 1840, with additions of later dates.

41 - Oxley Report of 1810, page 573.

42 - HRA 3-2, page 65.

43 - HRA 3-2, page 62 .

44 - Knopwood 29.6.1814.

45 - Knopwood 14.7.1814 and 8-9.4.1815.

46 - Knopwood 14.12.1815.

47 - HRA 3-3, page 572 (spring 1817).

48 - HTG 24.10.1818 and Knopwood 20.8.1817.

49 - HTG 1.11.1817.

50 - Knopwood 5.1.1814.

51 - Knopwood 28.3.1816.

52 - HTG 8.5.1819.

53 - HTG 29.6.1816.

54 - HTG 2.5.1818

55 - HTG 3.10.1818.

56 - Knopwood 15.11.1819.

57 - HRA 3-3, page 681 . 


\section{Frank Bolt}

58 - Knopwood 11.2.1820.

59 - Knopwood 21.6.1823.

60 - Lord, R., 1976: INSCRIPTIONS IN STONE. Hobart, page 170.

61 - HTG 14.4.1822.

62 - HTG 5.12 .1823$.

63 - Knopwood 8.10.1825.

64 - Independent 13.12.1834.

65 - Cornwall Chronicle 16.1.1836.

66 - Lord, R., 1976: INSCRIPTIONS IN STONE. Hobart, page 185.

$67-$ H.T. Courier 14.6.1854.

68 - Notes: $1 /$ 'the residence of her son-in-law' : now the 'Southlea' property of Mr. John walch along the Southern Outlet Road, 2/'One lady who still survives': although the number of women in the original Bowen settlement was very small I was unable to determine who she was.

69 - In the language of the day this meant that she was a member of a domestic situation in which someone else was the main provider. Collins later frequently used similax descriptions to indicate the wives, children and domestic staff of settlers. 